\title{
School-Based Prevention Child Sexual Abuse Program for School Age Children at Surabaya Indonesia
}

\author{
Fety Khosianah ${ }^{1 *}$
}

\author{
${ }^{1}$ Faculty of Psychology, Universitas Muhammadiyah Surabaya, Surabaya, Indonesia \\ *Corresponding author. Email: fety_kh@fpsi.um-surabaya.ac.id
}

\begin{abstract}
According to recent Indonesian statistics based on report from Ministry of Women's Empowerment and Child Protection of Indonesia at Juli 2019, there are increasing cases of child sexual abuse are reported. A lot children are becoming a victims of child sexual abuse. Experiencing child sexual abuse is frequently associated with negative effects on children. We need some prevention program to teach the children to avoid child sexual abuse. One of the effective prevention programs is school based prevention program for child sexual abuse. Many people agree that schools are at capacity in terms of taking on initiatives, so determining how to protect children and keep them safe. Within this context, school became a key location for the delivery of primary and secondary prevention program as they were become centres for education, included the whole child population and were places where children were at risk. This paper describes research conducted with child sexual abuse prevention program operating in some elementary school at Surabaya, Indonesia. Data are based on survey administered to identified child sexual abuse prevention program at some elementary school at Surabaya Indonesia.
\end{abstract}

Keywords: child sexual abuse, sexual abuse prevention program, school-based prevention program

\section{INTRODUCTION}

Child sexual abuse is serious problem for children worldwide with prevalence estimated at between $10-20 \%$ for girls and $5-10 \%$ for boys when sexual abuse is measured on continuum from exposure through unwanted touching to penetrative assaulut prior to 18 years of age [1]. Some examples of cases of sexual abuse against children include rape, incest, molestation, sexual harassment, and sodomy. The latest cases are also increase is child pornography and sexual abuse in cyber media.

The news reported by Detik News based on data from the Ministry of Women's Empowerment and Child Protection at Indonesia noted there were around 1500 reports of sexual abuse against children. This data is recorded nationally from the KPPPA (Kementrian Perlindungan Perempuan dan Anak) online information system as of January-June 2019 [2]. Cases of sexual assault can happen to anyone, anytime and anywhere. This is what causes the need for integrated cooperation to take some form of preventive action for potential victims which must be supported by repressive measures for the perpetrators and efforts to provide assistance for the victims. Perpetrators of sexual abuse against children today not only come from adults but the perpetrators can also come from among children [1].

Children who are victims of sexual abuse not only experience physical trauma, psychological or mental, can even end in death. Various psychological and social impacts make it difficult for victims of sexual abuse on children to recover from their trauma. Psychological effects include mental trauma, fear, shame, anxiety, even suicidal thoughts or attempts. According to the research of Orange \& Brodwin [3], and Powel (1991) [4], the social impacts usually experienced by victims of sexual abuse on children include, for example, cynical treatment from the surrounding community, fear of being involved in association and so on. If the victims of rape are children, then chances are they will recover even more difficult.

Some impacts that have been documented by several researchers such as Kliegman [5] Stander [6] Lane [7], about the effect of sexual abuse on children can cause anxiety, aggressive behavior, paranoia, post-traumatic stress disorder, depression, increased suicide attempts, disassociative disorders, low self-esteem, hypersexuality, post traumatic stress disorder, drug abuse, damage and pain to the genital organs, deviant sexual behavior, fear of a person or place, sleep disorders, aggressive, eating disorders, anxiety, withdrawal, depression, somatization, decreased performance in school, and a number of increased rape rates for victims of sexual abuse in childhood, victims of sexual abuse who did not receive adequate treatment could potentially become perpetrators of child sexual abuse and later on [7] [8].

In Indonesia there are several researchers who develop prevention child sexual abuse program such as Khosianah $\&$ Suminar [9] which develop preventing child sexual abuse program for pre-puberty girl, Hartatik [10] which creating preventing sexual abuse for girl with mental retardation, Justicia [11] which is creating preventing child sexual abuse program for pre school age children with underwear rules. The results of the Khosianah and Suminar research showed an increase in knowledge about how to protect themselves from child sexual abuse in pre-puberty children by $25 \%$ [9]. Also, Hartatik, found that the same increasing of knowledge for girl with mental retardation about how to protecting themselves from sexual abuse [10]. In Justicia [11] research about underwear rules for preschool age children, is 
designed for the parent to teach their preschool age children to aware with their body and their private part.

That research only for specific target, but there are so many children have the potential to become victims of sexual abuse. So, we need a program that can reach more children to understand how to preventing themselves from sexual abuse. This research are explain how school based prevention child sexual abuse program develop on some schools at Surabaya.

\section{METHODS}

The most commonly used method to prevent child sexual abuse is teaching children lesson to school-based program. According to the reasearcher about preventing child sexual abuse programs there are several tips for developing child sexual abuse program.

Program should include children as physically active learning participants, combining the techniques of modeling, group discussion, and role-playing/ rehearsal, should be broken into multiple sessions [12] [13] and be conducted at least annually, building on skills learned the previous year [12].

Programs should be developmentally appropriate for the targeted age group [14]. Ideally, an effective prevention programs targeted to young children do not use abstract concepts, provide many chances to practice skills, teach important concepts multiple times, teach the program over several days, and present the program in a way that is engaging to the children.

Programs should be culturally sensitive and adaptable for use within varying school contexts (age, race, special needs, etc). Programs should incorporate parents or caregivers into prevention efforts due to their key role in protecting children from abuse [15] [13]

Professionals delivering these prevention programs should have a through knowledge of child sexual abuse, including how to respond appropriately to disclosures. Programs should include an evaluation component with measurable outcomes.

Although research is limited on the effects of specific curricula, we recommend that schools seek to implement programs that include an evidence-based curriculum if possible. This research is to systematically asses evidence of the effectiveness of school-based education programmes for the prevention of child sexual abuse.

Specifically, to assess whether: programmes are effective in improving students' protective behaviours and knowledge about sexual abuse prevention; behaviours and skills are retained over time; and participation results in disclosures of sexual abuse, produces harms, or both.

Finkelhor, et all [16] identified 12 elements needed to be considered in developing a program to prevent sexual abuse against children as a preventive measure, including:

a. Content of knowledge about sexual abuse

b. Disturbances (Bulies)

c. Good and polite touch (Good Touch Bad Touch)

d. Confusing Touch

e. Incest

f. How to scream and scream that can attract attention

g. Steps for reporting events in adults h. The occurrence of abuse in children is not his fault

i. Opportunity to practice it in front of the class

j. Information that can be brought home

k. Meeting with parents

1. Repeat material for more than one day

In preparing the material, according to Khosianah [17] it should be adjusted to the child's development and consider the material according to their respective age.

Tutty 1995, identified a series of core concepts included in this program, namely naming body parts; recognize polite touches, impolite touches and confusing touches; ownership of his own body; permission to say "No"; secrets about touch that should not be stored; and report to adults until they believe.

In this research, we create namely naming body parts; recognize polite touches, impolite touches and confusing touches; ownership of his own body; permission to say "No"; secrets about touch that should not be stored; and report to adults until they believe it, also teach them how to protect them selves with some protection moves.

\section{RESULTS AND DISCUSSION}

Almost all participants have a good cognitive understanding of the parts of the body that must be protected. 6 percent of participants are still lacking understanding (score 40), 60 percent have sufficient level of understanding, and as many as 20 percent (score 80 ) have a good level of understanding, and as many as 14 percent have an excellent level of understanding (value 100).

Based on the results of the study, it can be concluded that the average child already understands the personal body of each, and already understand how to protect his body by wearing complete clothing and understand the limitations of touch that may and should not be done by others to them.

\section{CONCLUSION}

Along with age characteristics, effects according to gender need to be determined. Most of child sexual abuse prevention studies have found that there is no differences according to gender [18]; Kolko, Moser, \& Hughes, 1989), but three studies found school-aged girls to be more knowledgeable about child sexual abuse and its prevention compared with boys [16] Hazzard, Kleemeier, \& Webb, 1990; Sigurdson, Strang, \& Doig, 1987). Given that Boys are also at risk for sexual abuse, it is important to ensure that boys are able to learn the concepts and skills taught in personal safety programs. Thus, a second purpose of the study was to determine if a personal safety program has differential effects on boys and girls.

In this research we found that almost $60 \%$ of girls are more knowledgeable about child sexual abuse and its prevention compared with boys. 
Seksual Pada Remaja Putri Penderita Retardasi Mental Ringan., Surabaya: Thesis (Unpublished), Fakultas Psikologi Universitas Airlangga, 2000.

[11] R. Justicia, "Program Underwear Rules untuk Mencegah Kekerasan Seksual Pada Anak Usia Dini," Jurnal Pendidikan Anak Usia Dini, vol. 9, no. 2, pp. 217-232, November 2016.

[1] K. Walsh, K. Zwi, S. Woolfenden and A. Shlonsky, "Assessing the effectiveness of schoolbased sexual abuse prevention programs," in Family Matters No 97, Melbourne, Australian Institute of Family Studies, March 2016, 84 pp., 2016, pp. 5-15.

[2] E. Safitri, "www.detik.com," detikNews, 5 September 2019. [Online]. Available: news.detik.com/berita/d_4694561/kementrian-pppacatat-1500-laporan kekerasan-seksual-pada-anak. [Accessed 21 November 2019].

[3] I. Paramastri, J. E. Prawitasari, Y. S. Prabandari and E. Ekowarni, "Buklet sebagai media pencegahan terhadap kekerasan seksual pada anak-anak. Booklet as a preventive media of child sexual," Jurnal Kesehatan Masyarakat Nasional, vol. 2, p. 6, Oktober, 2011.

[4] J. S. Nevid, S. A. Rathus and B. Greene, Psikologi Abnormal Edisi Ke 5, Jilid 2, Jakarta: Penerbit Airlangga, 2005.

[5] R. M. Kliegman, R. E. Behrman, H. B. Jenson and B. F. N. Stanton, Nelson Textbook Of Pediatrics, Philadhelpia: Saunders Elsevier., 2007.

[6] V. Stander, C. B. Olson and L. L. Merril, "Selfdefinition as a survivor of childhood sexual abuse among navy," Journal of Consulting and Clinical Psychology, vol. 70, p. 369-377, 2002.

[7] M. Erooga and H. Massson, Children and Young People Who Sexually Abuse Other: Current Developments and Practice Responses 2nd Edition, 2nd ed., M. Erooga and H. Massson, Eds., London: Routledge Taylor and Francis Group, 2006, p. 23.

[8] C. Wenar, Developmental psychopathology from infancy through adolescent., New York: Mc GrawHill, Inc., 1994.

[9] F. Khosianah and D. R. Suminar, "Pengaruh pelatihan perlindungan diri terhadap kemampuan menghindari child sexual abuse pada anak perempuan usia pra pubertas," Insan, vol. 6, no. 2, pp. 67-48, Agustus 2004.

[10] R. Hartatik, Pengaruh Program Perlindungan Terhadap Kemampuan Menghindari Pelecehan
[12] K. M. Davis and C. Gidycz, "Child sexual abuse prevention programs: A meta-analysis," Journal of Clinical Child Psychology, vol. 29, no. 2, pp. 257265., 2000.

[13] K. J. Topping and E. G. Barron, "School-based child sexual abuse prevention programs. A review of effectiveness.," Review of Educational Research., vol. 79, no. 1, pp. 431-463., 2009.

[14] S. Wurtele and J. Owens, "Teaching personal safety skills to young children: An investigation of age and gender across five studies," Child abuse \& neglect, vol. 21, pp. 805-14, 1997.

[15] M. C. Kenny, V. Capri, R. R. Thakkar-Kolar, E. E. Ryan and M. K. Runyon, "Child sexual abuse: From prevention to self-protection.," Child Sexual Abuse Review, vol. 17, pp. 36-56, 2008.

[16] D. Finkelhor, N. Asdigian and J. DziubaLeatherman, "The effectiveness of victimization prevention instruction: An evaluation of children's responses to actual threats and assaults.," Child Abuse \& Neglect, vol. 19, pp. 141-153, 1995.

[17] F. Khosianah, "Strategies Based On Child Developmental Stages To Prevent Child Sexual Abuse," Humanities and Social Sciences Reviews, vol. 7, no. 3, pp. 282-292, 23 April 2019.

[18] G. A. Bogat and M. P. McGrath, "Preschoolers' cognitions of authority, and its relationship to sexual abuse education," Child Abuse \& Neglect, vol. 17, pp. 651-662, 1993. 